Assoc. Prof. Dr. Ishak KOZIKOGLUa

Original scientific paper

Van Yuzuncu Yil University

UDC: 371.14

Van, Turkey

Prof. Dr. Nuray SENEMOGLUb

Hacettepe University

Ankara, Turkey

\title{
PREDICTORS OF THE CHALLENGES FACED BY BEGINNING TEACHERS: PRE-SERVICE TEACHER EDUCATION COMPETENCY AND PROFESSIONAL COMMITMENT ${ }^{1}$
}

\begin{abstract}
The purpose of this study is to determine to what level beginning teachers' perceptions concerning the competency of pre-service teacher education and their professional commitment predict the challenges they face. This study was conducted with 942 beginning teachers working at istanbul, Konya, Gaziantep and Van provinces in Turkey. The data were collected with the scale of challenges faced by beginning teachers, teachers' perceptions scale concerning the competency of preservice teacher education and teachers' professional commitment scale developed by the researchers. Descriptive statistics, MANOVA, Pearson Product-Moment Correlation Coefficient and stepwise regression analysis were used for data analysis. As a result of the study, it was found that beginning teachers face challenges at moderate level in their first year. Furthermore, it was found that three variables ("relations with students, colleagues, administrators, parents and society", "teaching planning and implementation " and "commitment to the profession") are significant predictors explaining approximately one third (\%30.4) of the variance concerning the challenges faced by beginning teachers.
\end{abstract}

Keywords: Beginning teachers, challenges, pre-service education, professional commitment.

\section{Introduction}

Teachers have great responsibilities for educating qualified human power, which is necessary for social development and welfare. However, there are many questions that need to be answered in teaching-learning process as much as in the process of curriculum development in the education system. It does not seem possible that one person can answer all of these questions regardless of his/her educational level. Therefore, it is a big mistake to expect to take healthy decisions by leaving the teacher alone in responding to all these questions. In this process, the teachers should be provided with the necessary help and support (Erturk, 2013).

\footnotetext{
aishakkozikoglu@yyu.edu.tr

bprofdrnuray@gmail.com

'This research was obtained from PhD study of first author titled as "First Year in Teaching: Challenges

Faced by Novice Teachers, Their Pre-service Education's Competency and Commitment to the

Profession".
} 
As three basic requirements of teaching profession, a teacher needs to have professional content knowledge, teaching pedagogical skills and general cultural knowledge. For this reason, prospective teachers should learn the basic concepts and principles of their profession and they should be trained to work in different teaching-learning environments in pre-service teacher education (Bostock, 2019). Even though beginning teachers have received a qualified pre-service education, they need comprehensive guidance in the first years of their profession. Therefore, mentoring has long been considered as an effective tool to support and adapt beginning teachers to the profession during the induction period (Bressman, Winter \& Efron, 2018).

An important aspect of the teaching profession is the ability to make a healthy transition between classroom learning and practice. Beyond the excitement of beginning the teaching profession, beginning teachers often face many difficulties in the profession. The discrepancy between their vision and real practices makes this situation more difficult than expected. They face with the challenge of difficult tasks that experienced teachers reject (Podsen \& Denmark, 2000; Cited in Keengwe \&Adjei-Boateng, 2012). Beginning teachers are often exposed to the most challenging lessons. In addition, many beginning teachers have a very fast orientation to school politics and procedures before beginning the profession. During the school time, there is no time for teachers to discuss topics such as pedagogical methods, time and classroom management with other teachers (DePaul, 2000).

There is a general belief that teacher education curricula prepare prospective teachers for real classroom conditions. However, many of the beginning teachers have many difficulties in their first year of profession (Kumi-Yeboah \& James, 2012). Many beginning teachers think that after they have graduated from pre-service their teacher education, they will be able to apply what they have learned during the profession. However, especially during induction years of teaching, most of the teachers experience shock because of the challenges of a new context of teaching. Therefore for many beginning teachers professional experiences becomes extremely hard as they struggle for adapting to the new profession (Farrell, 2016).

Pre-service teacher education, which provides prospective teachers the professional content knowledge, professional attitudes and skills necessary for the professional qualification, is an important part of professional development. A qualified pre-service education will ensure teacher motivation and retention in the profession (Lim, Cock, Lock \& Brock, 2009). Preservice teacher education should enable prospective teachers to develop their teaching views and allow the students to experience a linkage between practice and theory (Hennissen, Beckers\& Moerkerke, 2017).

Pre-service education has an important place for prospective teachers to be able to cope with the challenges they may face in the first years of their careers. Prospective teachers should know how to establish an effective teaching-learning environment before beginning the profession (Ballantyne, 2005). The limited experience in pre-service teacher education causes the gap between theory and practice. Therefore, pre-service teachers are needed to develop learning and teaching experiences that meet pedagogical demands of the profession especially in induction years (Lancaster \& Bain, 2019).

Beginning teachers are a different group experiencing inadequate working conditions that can result in their leaving the profession. As they are exposed to different professional experiences, it is important to determine their commitment to the profession and their experiences. Teachers' view of the profession affects their attitudes and beliefs towards 
students (Michel, 2013). Thus, it is thought that beginning teachers' professional commitment may affect the challenges they face in the first year of the profession.

The time and energy that teachers spend on teaching shows their level of commitment. A teacher who is highly committed to the profession spends energy and time for the quality of profession and student success. A teacher who is moderately committed to the profession works on specific aspects of the profession. Those, who are not committed to their profession or less committed, are not willing to work for their professional development and are unconcerned with the profession (Glickman et al., 2005, Cited in Barbara \& Grady, 2007). Professional commitment of teachers and their job satisfaction are two important elements. In order to improve teacher education quality, it is of great importance to develop committed teachers who show commitment to the students, institution, the profession itself, society and professional values (Sharma, 2019).

Professional commitment refers to the feeling of engagement towards the profession which includes two important elements that are being proud of the profession and having a strong desire for professional development. A committed teacher spends time for the students and profession during and even after school hours. He/she studies hard for developing students' skills and performance. In other words, committed teachers not only strive for development of students but also put great effort for their own professional and individual development (Bashir, 2017). Teachers' professional satisfaction is a significant contributor to teachers' retention in the profession, professional commitment and school effectiveness (Shann, 2010). In this case, it is important to determine teachers' professional commitment that is indicative of how meaningful the teachers' professional experiences are (Solomon, 2008).

\subsection{Aim and Importance of the Study}

As emphasized in the literature, the early years of the teaching profession are very important for beginning teachers and there are many challenges to overcome. Unfortunately, there are very few studies that comprehensively examine the challenges that beginning teachers face in their first year of the profession and the variables that affect them. The purpose of this study is to identify the challenges faced by beginning teachers; determine to what level teachers' perceptions concerning the competency of their pre-service teacher education and their professional commitment predict the challenges they face. For this reason, the following questions are addressed in this study:

1- What are the challenges that beginning teachers face during their first year in the profession?

2- Do the challenges that beginning teachers face change according to the provinces they work?

3- At what level teachers' perceptions concerning the competency of their pre-service teacher education and their professional commitment predict the challenges they face?

\section{Method}

\subsection{Research Model}

Correlational survey model was used in this study. Correlational survey model aims to analyze the existence and level of correlation between two and more variables (Fraenkel, Wallen \& Hyun, 2012), so it is an appropriate model for the purpose of this study. 


\subsection{Population and Sample}

The population of the study consists of beginning teachers in the academic year of 2014-2015 working in Turkey. In this study, purposive sampling method was used. In purposive sampling, the researcher determines the sample based on the purpose of the study (Fraenkel, Wallen\& Hyun, 2012). By using purposive sampling method, the sample was determined among the provinces in which beginning teachers were assigned at most in order to obtain rich data. Stratified sampling method as one of the purposive sampling method was used in determining the provinces to be sampled. In stratified sampling method, the population is separated to the strata and the sample is determined from the determined strata (Patton, 2002). In this study, socio-economic development level of the provinces was taken into account in determining the strata and the number of the beginning teachers assigned to each province in the strata was taken as basis in the sampling. Accordingly, the provinces in which beginning teachers were assigned at most in 2014-2015 academic year were selected for sample that are the provinces of Istanbul (high socio-economic development level), Konya (medium high), Gaziantep (medium low) and Van (low).

It is important for the sample size to work on a sample that is large and representative of the population as far as possible considering the time and energy (Fraenkel, Wallen and Hyun, 2012). In this study, it was tried to reach as many beginning teachers as possible by considering the number of beginning teachers in the determined provinces. In each province, the research was conducted with approximately $10 \%$ of the beginning teachers (eg. The number of teacher assignments in Istanbul: 1339/the number of sample: 141; the number of teacher assignments in Konya: 1432/the number of sample: 170). The sample of the study consists of 942 teachers. The characteristics of the teachers in the sample are presented in Table 1.

Table 1. The characteristics of the teachers in the sample

\begin{tabular}{lll}
\hline Characteristic & Category & Number (N) \\
\hline Gender & Female & 574 \\
& Male & 368 \\
& Total & 942 \\
\hline Department & Math & 142 \\
& Primary education & 120 \\
& Foreign language & 122 \\
Science & 112 \\
Social sciences & 145 \\
& Religion & 129 \\
& Vocational courses & 97 \\
& Special talent courses & 75 \\
\hline Province & Istanbul & 141 \\
& Konya & 170 \\
& Gaziantep & 243 \\
& Van & 388 \\
\hline
\end{tabular}

\subsection{Data Collection Tools}

Data were obtained by using "Challenges Scale Faced by Beginning Teachers", "Teacher Perceptions Scale Concerning Competency of Pre-Service Education" and "Teachers' Professional Commitment Scale" developed by the researchers. "Challenges Scale Faced by Beginning Teachers" consists of 35 items and five sub-dimensions that are "teaching planning 
and implementation", "classroom management", "relations with colleagues and school administrators", "relations with physical environment and society", "physical infrastructure and facilities of the school". The Cronbach Alpha coefficient of the scale was calculated as 0.92. "Teacher Perceptions Scale Concerning Competency of Pre-Service Education" consists of 25 items and two sub-dimensions that are "teaching planning and implementation" and "relations with the students, colleagues, school administrators, parents and society". The Cronbach Alpha coefficient of the scale was calculated as 0.94. "Teachers' Professional Commitment Scale" consists of 20 items and three sub-dimensions that are "commitment to the profession", "dedication to the students" and "devotion to the profession". The Cronbach Alpha coefficient of the scale was calculated as 0.90 . These data show that the scales are reliable data collection tools.

\subsection{Data Analysis}

The frequency, percentage and arithmetic mean values were calculated to determine the level of the challenges faced by beginning teachers. Responses to the scale items are rated as "None", "Rarely", "Sometimes", "Often" and "Always". In order to interpret arithmetic mean values, range values were calculated using the formula 5-1 $=4,4 / 5=0.80$. These range values were interpreted " 1 to 1.79 " as very low level (none), "1.80 to 2.59 " as low level (rarely), "2.60 to 3.39" as moderate level (sometimes), "3.40 to 4.19" as high level (often), "4.20 to 5.00" as very high level (always). Multivariate analysis of variance (MANOVA) was used to compare the challenges faced by beginning teachers according to the province that they work. In case of a significant difference after comparison, Scheffe test was used to determine from which groups the difference originated. Stepwise regression analysis was used to determine whether beginning teachers' perceptions concerning competency of pre-service education and their professional commitment significantly predicted the challenges faced by beginning teachers in the first year of the profession. Relationships between these variables were determined by using Pearson Product Moments Correlation Coefficient ( $r$ ). Prior to the analysis, dependent and independent variables were examined according to the assumptions of stepwise regression analysis. As a result, multivariate normality and linearity were achieved, it was concluded that there is not multicollinearity problem.

\section{Results and Discussion}

\subsection{Results and Discussion Concerning the First Sub-Problem}

Concerning the first sub-problem of the study; the findings and discussion are presented below based on sub-dimensions of the scale.

\subsubsection{Teaching planning and implementation}

Beginning teachers stated that they have difficulty in teaching planning and implementation at low level $\left(\overline{\bar{X}}_{=2.52}\right)$. On the other hand, unlike the findings of this research, in some studies in the literature (Gaikhorst, Beishuizen, Roosenboom \& Volman, 2017; Sali \& Kecik, 2018), it was determined that they experience great challenges in teaching. Thus, it seems that beginning teachers have difficulty in planning and implementation of teaching activities in the first year of the profession. 
More than half of the teachers stated that they sometimes have difficulty (52.5\%) in deciding how much time to allow for the implementation of the subjects. This shows parallelism with the results of study conducted by Ergunay and Adiguzel (2019). Time management requires planning which is very difficult for teachers who are new to the profession (Monica \& Kuswandono, 2019). In this case, it can be said that the beginning teachers are not experienced enough to plan and use the time effectively and efficiently.

More than half of the teachers (51.4\%) indicated that they sometimes have difficulty in planning the lesson according to students' level. It is stated that curricula in Turkey are developed based on constructivism. One of the most fundamental principles of constructivism is that students need to have a sufficient level of readiness, in other words, they have the necessary prerequisite knowledge. In this sense, it is necessary to plan and implement teaching in accordance with the student's level in order to conduct an effective and productive learning. The more a teacher has experiences with the students, the more he/she knows the student and arranges the teaching-learning environment accordingly (Senemoglu, 2015). Therefore, the fact that beginning teachers do not have too much experience with students as they are in the first year of their profession may be considered as an important reason for their having difficulty in planning and implementation of teaching appropriate to their students' level.

More than half of the teachers (55.6\%) stated that they sometimes (33.5\%) and often $(22.1 \%)$ have difficulties in organizing activities to support the special talents of the students. There are similar research results (Keengwe \& Adjei-Boateng, 2012; Toker Gokce, 2013) in the literature. Beginning teachers perceive "dealing with different needs and interests of the students in the class" as an important challenge (Gaikhorst et al, 2017). This study supports these results. These results show that beginning teachers face challenges to practice teaching appropriate to the individual differences and to improve their special talents.

\subsubsection{Classroom management}

Beginning teachers stated that they experience the challenges in classroom management at moderate level $\left(\bar{X}_{=2.92}\right)$. Similarly, Goodwin (2012) pointed out that the most important challenge experienced by beginning teachers is classroom management. In this case, it can be said that classroom management is an important source of difficulty for beginning teachers. It was found that more than half of the beginning teachers sometimes (26.6\%) and often (27.1\%) have difficulty in organizing effective learning environments in crowded classes, and nearly half of them sometimes (29.5\%) and often (17.9\%) have difficulty in maintaining classroom management in crowded classroom. In many studies in the literature (Gaikhorst et al, 2017; Keengwe \& Adjei-Boateng, 2012; Sali \& Kecik, 2018; Toker Gokce, 2013), it was found that beginning teachers face challenges in classroom management due to the crowded classes. Also, adverse behaviors are more likely to be seen in crowded classrooms (Blatchford, Bassett \& Brown, 2011). Class size can be effective on student learning in many ways such as student interaction, adverse behaviors, dealing with special needs of the students, time allocated for teaching, teaching methods, variety of activities, etc. Thus, class size is considered as a crucial factor for students' academic achievement (Abosede, 2018). As emphasized in the literature, it is seen that classroom size has an important effect on the educational environment. Although the qualities and characteristics of teachers and students are effective in classroom management, it is noteworthy that crowded classes are a serious disadvantage for beginning 
teachers. It can be said that the crowded classroom prevents the management of the teaching effectively, thus causing classroom management problems.

Almost half of the beginning teachers were found to have difficulty in preventing adverse student behaviors in the classroom. In the studies both in Turkey (Ergunay and Adiguzel, 2019; Sali \& Kecik, 2018; Toker Gokce, 2013) and abroad (Keengwe \& Adjei-Boateng, 2012; Michel, 2013; Monica \& Kuswandono, 2019; Mudzingwa \& Magudu, 2013)conducted with beginning teachers, it was found that beginning teachers have difficulties in classroom management in parallel with this study results. Therefore, it can be said that beginning teachers have serious difficulties in preventing adverse student behaviors in classroom.

\subsubsection{Relations with colleagues and school administrators}

Beginning teachers stated that they have difficulty in relations with colleagues and school administrators at low level $\left(\overline{\bar{X}}_{=2.36}\right)$. In parallel with this study results, Michel (2013) found that beginning teachers do not experience serious difficulties with their colleagues in the first year of profession. So it can be said that beginning teachers can establish positive relationships with their colleagues in general. In teaching profession, the sincere behavior of other people in the school has a strong influence on teacher (Barbara \& Grady, 2007). It is emphasized in some studies in the literature (Farrell, 2012; Ozgan, 2013; Sali \& Kecik, 2018) that beginning teachers' good communication and cooperation with their colleagues is useful in their passing the process (first year in teaching) more easily and efficiently. This suggests that other teachers in the school have a significant influence on the beginning teachers. Research has shown that beginning teachers need the support of school administrators and other teachers in the school in order to adapt to the school environment in the first years of the profession and make a better transition to the teaching profession (Mudzingwa \& Magudu, 2013). All of this reveals the importance of positive relations with colleagues. Thus, beginning teachers' not having serious problems in their relations with colleagues in this study can be considered as a positive situation.

Approximately one-third of the beginning teachers stated that they sometimes (19.1\%) and often (10.1\%) do not receive the necessary support from the school administrators to cope with the challenges they face and they thought that school administrators sometimes (19.3\%) and often (15.7\%) do not prepare adequate environments for individual and professional development. Similarly, Michel (2013) concluded that beginning teachers do not have serious problems in relations with school administrators in the first year of their profession. However, in some studies (Barkauskaite \& Meskauskiene, 2017; Sari \& Altun, 2015; Sali \& Kecik, 2018; Toker Gokce, 2013), it was determined that beginning teachers have difficulties in relations with school administrators. Mentoring and coaching are essential for beginning teachers in order to provide support and guidance in areas of professional and personal development (Vikaraman, Mansor \& Hamzah, 2017). However, in this study it can be said that school administrators do not provide sufficient support, guidance, feedback and the necessary environment for beginning teachers. In other words, it seems that the expectations of the beginning teachers from the administrators have not been met adequately. The administrators of educational institutions have a multifaceted profession such as setting a mission and vision, forming a goal, organizing duties, motivating employees, reviewing results and making decisions. These tasks cannot be performed without effective communication. Effective communication requires active listening, understanding, empathy and feedback 
(Senemoglu, 2007). Thus, it is possible to say that school administrators do not fulfill their duties effectively in this sense.

Approximately half of the beginning teachers stated that mentor teacher sometimes (34.6\%) and often (11.3\%) does not adequately support them on classroom practices and more than half of the teachers stated that the professional knowledge of their mentor teacher sometimes (25.8\%) and often (25.8\%) is inadequate in solving the problems they face in practice. The results of this study are in parallel with the results of many studies in the literature (Sali \& Kecik, 2018; Sari \& Altun, 2015; Yesilyurt \& Karakus, 2011). Many beginning teachers expect from the mentor teacher much more than just an open door and a friendly greeting. They want to regularly meet with the mentor teacher and take advantage of their experiences (DePaul, 2000). When the results of this study and the studies above are considered together, it can be concluded that beginning teachers cannot get the support they need from the mentor teachers in the first year of the profession.

\subsubsection{Relations with physical environment and society}

Beginning teachers stated that they have difficulty in relations with the physical environment and society at a moderate level $\left(\overline{\bar{X}}_{=2.67)}\right.$. It was found that almost half of the teachers have difficulty in adjusting to the geographical/physical characteristics of the region where they work. These results support the results of Yesilyurt and Karakus (2011). Beginning teachers' working usually in small schools and deprivation areas makes it more difficult for them to adapt to both the school and environment. In addition, geographical loneliness of rural areas is a serious obstacle for beginning teachers (Theobald \& Nachtigal, 1995; Cited in Barbara \& Grady, 2007). The teachers', especially working in the east, having difficulties in this sense may be result of negative climate and environmental conditions, and teachers' not being accustomed to the characteristics of the physical environment.

Approximately half of the teachers stated that they sometimes (23.2\%) and often (16.2\%) have difficulty in adapting to the socio-cultural characteristics of the society; more than half of the teachers stated that they sometimes (48.2\%) and often (11.5\%) have difficulties in relations with the society because they are unfamiliar to the region. These results overlap with the results of Duran, Sezgin and Coban (2011). Beginning teachers usually begin the profession in the societies that they are not familiar with. Living and working in unfamiliar communities causes certain difficulties (Roehrig, Pressley \& Talotta, 2002). More than half of the teachers who face challenges in this sense work in the province of Van. It can be said that, especially the teachers who work in the east, have difficulty because of the reasons such as the difference between cultural characteristics or the life style of the society where they work and their own culture. Because beginning teachers who are assigned to a social environment with a cultural structure different from the culture that they lived have adaptation challenges. One of the reasons for the conflict in social and cultural terms is because of the fact that rural societies are often conservative and may be closed to different social, cultural, political views or behaviors. Most of the beginning teachers emphasize that challenge (Gaikhorst et al, 2017; Mudzingwa \& Magudu, 2013; Sali \& Kecik, 2018). Therefore, it is important to ensure beginning teachers' effective adaptation to the social environment of the region and the socio-cultural characteristics of the society.

Approximately one-third of the beginning teachers indicated that they often $(19.4 \%)$ and always (14.8\%) have difficulty in adapting to the school environment because of insufficient 
social facilities. This result overlaps with the results of Duran, Sezgin \& Coban (2011). Thus, it can be said that beginning teachers have difficulties due to the limited social and cultural possibilities of the region they have been assigned to. This can be resulted from the fact that beginning teachers usually begin the profession in rural areas. Considering the physical and psychological burden of the teaching profession; the lack of living spaces where beginning teachers can spend their time, discharge themselves and develop themselves professionally/individually can be regarded as an important shortcoming.

\subsubsection{Physical infrastructure and facilities of the school}

Beginning teachers stated that they face the challenges arising from the physical infrastructure and facilities of the school at moderate level $(\overline{\bar{X}}=3.20)$. It was found that most of the beginning teachers have difficulty in organizing the educational environment due to the lack of materials. More than half of teachers stated that the school architecture sometimes (27.6\%) and often (27.9\%) prevented them from organizing effective educational environment, they sometimes (26.6\%) and often (30.3\%) have difficulty in reaching different teaching materials due to the limited facilities in the school and environment, they sometimes $(27.6 \%)$ and generally (25.6\%) have difficulty in applying the educational activities they have planned due to the physical inadequacies of the classes. In many studies conducted in the literature (Keengwe \& Adjei-Boateng, 2012; Mudzingwa \& Magudu, 2013; Sali \& Kecik, 2018; Toker Gokce, 2013; Yesilyurt \& Karakus, 2011), similar results were reached.

Considering the results of the studies above and this study, it can be said that beginning teachers face challenges due to the reasons such as physical inadequacies of the classes (technological tools, boards, visual materials, etc.), school architecture's (school gardens, classrooms, laboratories, sports halls, etc.) not being arranged to support effective learning, inadequacies of teaching materials because of the limited facilities in the school and the environment. This suggests that school and classroom environments do not have sufficient physical infrastructure and facilities for effective learning. This results show that school architecture, school physical arrangements, physical and technological facilities should be organized to support effective learning.

Beginning teachers face even more difficulties when they are assigned to the schools with low socio-economic levels, where the number of disadvantaged students with limited opportunities is high (Jensen et al., 2012). In undergraduate education, prospective teachers are generally doing teaching practice at good schools in terms of physical infrastructure and possibilities. But it can be said that beginning teachers have difficulty in adapting to the existing conditions in the first year of the profession because they begin the profession in the schools with limited possibilities in rural areas, which prevent them to make effective teaching.

\subsection{Results and Discussion Concerning the Second Sub-Problem}

Concerning the second sub-problem of the study, it was found that there was a significant difference in the scale scores according to the province that beginning teachers work (Wilks' Lambda .837, $\mathrm{F}(15,2578)=11.476, \mathrm{p}<.05)$. As a result of the bilateral comparisons made with the Scheffe test, it was found that there was a significant difference between the teachers working in the province of Van and the teachers working in the provinces of Istanbul, Konya and Gaziantep in favor of the teachers working in the province of Van. In other words, the 
teachers working in the province of Van stated that they faced challenges more than the teachers working in the provinces of Istanbul, Konya and Gaziantep.

Many economic, social and cultural variables are used in determining the level of socioeconomic development (Ministry of Development, 2013). It is known that many of these variables directly or indirectly affect education. Low socio-economic level causes many problems such as health problems, lack of school-family cooperation etc. (Akdag, 2014). Therefore, in the provinces with low socio-economic development level (E.g. Van province); economic status of families, education level, possibilities, student characteristics, cultural characteristics, opportunities of school and environment etc. can be considered as important reasons for beginning teachers to face challenges more.

\subsection{Results and Discussion Concerning the Third Sub-Problem}

Concerning the third sub-problem of the study, first of all, Pearson Product Moment Correlation Coefficients are presented in Table 2.

Table 2. Pearson Product Moments Correlation Coefficients Between All Variables Included in This Study

\begin{tabular}{|c|c|c|c|c|c|c|c|}
\hline Scales and sub-dimensions & (1) & (2) & (3) & (4) & $(5)$ & $(6)$ & (7) \\
\hline \multicolumn{8}{|l|}{ A. Competency of Pre-Service } \\
\hline \multicolumn{8}{|l|}{ Education } \\
\hline 1. Pre-service education (total) & 1.00 & & & & & & \\
\hline $\begin{array}{l}\text { 2. Teaching planning and } \\
\text { implementation }\end{array}$ & $.828^{* *}$ & 1.00 & & & & & \\
\hline $\begin{array}{l}\text { 3. Relations with the students, } \\
\text { colleagues, school } \\
\text { administrators, parents and } \\
\text { society }\end{array}$ & $.824^{* *}$ & $.554^{* *}$ & .1 .00 & & & & \\
\hline \multicolumn{8}{|l|}{$\begin{array}{l}\text { B. Teachers' Professional } \\
\text { Commitment }\end{array}$} \\
\hline 4. Commitment (total) & $\cdot 381^{* *}$ & $.340^{* *}$ & $.335^{* *}$ & 1.00 & & & \\
\hline 5. Commitment to the profession & $.260^{* *}$ & $.223^{* *}$ & $.243^{* *}$ & $.822^{* *}$ & 1.00 & & \\
\hline 6. Dedication to the students & $\cdot 375^{* *}$ & $.336^{* *}$ & $.328^{* *}$ & $.808^{* *}$ & $.477^{* *}$ & 1.00 & \\
\hline 7. Devotion to the profession & $.329^{* *}$ & $.312^{* *}$ & $.260^{* *}$ & $.713^{* *}$ & $.437^{* *}$ & $\cdot 541^{* *}$ & 1.00 \\
\hline \multicolumn{8}{|l|}{$\begin{array}{l}\text { C. Challenges Faced by Beginning } \\
\text { Teachers }\end{array}$} \\
\hline 8. Challenges (total) & $-.525^{* *}$ & $-.451^{* *}$ & $-.487^{* *}$ & $-.324^{* *}$ & $-.283^{* *}$ & $-.264^{* *}$ & $-.226^{* *}$ \\
\hline
\end{tabular}

According to Table 2, it is seen that there is a moderate, positive and significant relationship between total score of pre-service education competency scale and professional commitment scale $(r=.381 ; p<.01)$. According to this result, it can be said that as the competency of preservice education increases, teachers' professional commitment increases. A moderate, negative and significant relationship was found between total score of challenges faced by beginning teachers and pre-service education competency scale $(r=-.525 ; p<.01)$. According to this result, it can be said that the teachers who stated that their pre-service education is more competent face challenges less in the first year of profession. In addition; a moderate, negative and significant relationship was found between the total score of the challenges 
scale and professional commitment scale $(r=-.324 ; p<.01)$. According to this result, it can be said that as the teachers' professional commitment increases, they face challenges less.

The results of stepwise regression analysis of the data on the variables that are considered as predictors of the challenges faced by beginning teachers are presented in Table 3.

Table 3. The Results of the Stepwise Regression Analysis Concerning the Prediction of the Challenges Faced By Beginning Teachers

\begin{tabular}{llccc}
\hline Steps & Predictive Variables & 6 & $\begin{array}{l}\text { Predictive } \\
\text { Power }(R)\end{array}$ & $\begin{array}{l}\text { Explained } \\
\text { Variance }\left(R^{2}\right)\end{array}$ \\
\hline 1 & $\begin{array}{l}\text { Relations with the students, colleagues, school } \\
\text { administrators, parents and society }\end{array}$ & -.487 & .487 & .237 \\
\hline 2 & Teaching planning and implementation & -.262 & .534 & .283 \\
\hline 3 & Commitment to the profession & -.153 & .554 & .304 \\
\hline
\end{tabular}

According to Table 3, it is seen that the sub-dimensions of the teacher perceptions scale concerning competency of pre-service education that are "relations with the students, colleagues, school administrators, parents and society" and "teaching planning and implementation" and the sub-dimension of the professional commitment scale that is "commitment to the profession" can explain 30\% of the variance in challenges faced by beginning teachers. The results of the variance analysis for the stepwise regression analysis in Table 3 are presented in Table 4.

Table 4. The Results of the Variance Analysis Concerning the Prediction of the Challenges Faced By Beginning Teachers

\begin{tabular}{llllll}
\hline Source of Variance & $\begin{array}{l}\text { Sum of } \\
\text { squares }\end{array}$ & sd & $\begin{array}{l}\text { Mean of } \\
\text { squares }\end{array}$ & F & $\boldsymbol{p}$ \\
\hline Regression & $\begin{array}{l}77.437 \\
\text { Residual }\end{array}$ & 3 & 25.812 & 138.196 & .000 \\
\hline
\end{tabular}

According to Table 4, it is seen that the predictive power obtained from stepwise regression analysis in Table 3 is significant $\left(F_{(3,938)}=138.196, p_{<}<.000\right)$. The regression analysis on challenges faced by beginning teachers took place in three steps. Accordingly, it is seen that three variables are significant predictors for the contribution to the variance concerning the challenges faced by beginning teachers. In the first step, the sub-dimension of teacher perceptions scale concerning competency of pre-service education that is "relations with the students, colleagues, school administrators, parents and society" was included in the analysis explaining $23.7 \%$ of the variance. In the second step, the sub-dimension of the teacher perceptions scale concerning competency of pre-service education that is "teaching planning and implementation" was included in the analysis making $4.6 \%$ contribution to the variance. In the third step, the sub-dimension of the professional commitment scale that is "commitment to the profession" was included contributing $2.1 \%$ to the variance explained. The results of this analysis show that the three variables, that are important predictors of regression equality, can explain about one third (30.4\%) of the variance concerning the challenges faced by beginning teachers. When regression coefficients are examined, it is seen that there is a negative correlation between the challenges faced by beginning teachers and all three variables. On the other hand, it was found that the sub-dimensions of "devotion to the profession" and "dedication to students" do not make a significant contribution to the total variance. 
It is seen that the significant variables included in the analysis differ in their contribution to the variance explained. It is seen that the sub-dimension of the teacher perceptions scale concerning competency of pre-service education that is "relations with the students, colleagues, school administrators, parents and society" is the most important predictor of the challenges faced by beginning teachers $(r=.487)$. This is followed by the sub-dimension of "teaching planning and implementation" $(r=.534)$. Thus, it turns out that the competency of pre-service education that teachers have received can account for $28.3 \%$ of the variance concerning the challenges faced by beginning teachers. This suggests that effective preservice education is an important variable in explaining the challenges faced by beginning teachers. The quality of the instruction in schools is directly related to the pre-service education (Darling Hammond, 2000), because a qualified education takes place with effective teachers. Teacher training is very important in this process. Teacher education includes policies and practices designed to provide prospective teachers with the knowledge, skills and attitudes necessary to effectively perform their duties in class, school and larger community. Qualified pre-service teacher education ensures that the beginning teacher will be competent before entering the class (Thompson \& Power, 2015). These study findings support these views. Thus, it can be said that the competency of the pre-service education is an important variable on the challenges faced by beginning teachers.

In this study, it was found that the sub-dimension of the teacher perceptions scale concerning competency of pre-service education that is "relations with the students, colleagues, school administrators, parents and society" is the most important predictor of the challenges faced by beginning teachers. In Turkey, one of the teaching profession competences is "relations with school, family and society". Under this main competence; the sub-competencies are identified including recognition of the environment, utilization of environmental facilities, family participation and cooperation, etc (Turkish Education Association, 2009). Therefore, it can be said that the beginning teachers face more challenges because the pre-service education has not prepared them enough especially in the context of "school, family and society relations". This suggests that pre-service education should be of a quality that prepares prospective teachers for out-of-class (colleague, administrator, parent, society) situations. As a matter of fact, it is stated in the literature that the beginning teacher will be able to feel himself/herself successful in his/her profession if he/she adapts effectively to his colleagues, school administrators, school climate and conditions (Toker Gokce, 2013). In the study of Senemoglu (2011), prospective teachers, lecturers and beginning teachers stated that prospective teachers have the most competency in school experience and teaching practice and these courses should be given priority. However, in pre-service teacher education, preservice teachers apply theory only to a limited extent in practice. In other words, theory is not embedded in teaching practice (Hennissen, Beckers \& Moerkerke, 2017), as it is the case in teacher education curricula of Turkey. Therefore, it can be said that it is necessary to devote more time to school experience and teaching practices in pre-service education in order to be able to train teachers with professional competencies and ensure them to overcome the challenges they face in the first year of profession.

Another result obtained from this study is that the sub-dimension of professional commitment scale that is "commitment to the profession" accounts for $2.1 \%$ of the variance concerning the challenges faced by beginning teachers. This suggests that the commitment to the teaching profession is a significant variable of the challenges faced by beginning teachers in negative direction. In parallel with this study results, it is stated in the literature that teachers with professional commitment spend great effort both for student development and 
their own professional development (Bashir, 2017). Thus, it can be concluded that beginning teachers who feel more commitment to the profession face challenges less in the first year of profession.

\section{Conclusion and Suggestions}

As a result, it was concluded that beginning teachers face challenges at low level in subdimensions "teaching planning and implementation" and "relations with colleagues and school administrators", but face challenges at moderate level in sub-dimensions "classroom management", "relations with the physical environment and society" and "the school's physical infrastructure and facilities". In other words, they faced challenges mostly in inadequacy of the school's physical infrastructure and facilities, and classroom management respectively; faced challenges in relations with colleagues and school administrators at least. Furthermore, it was concluded that the most important predictor of the challenges faced by beginning teachers are "relations with the students, colleagues, school administrators, parents and society", "teaching planning and implementation" and "commitment to the profession", respectively. This suggests that the competency of pre-service education in preparing teachers for out-of-class (colleagues, administrators, parents, society) situations is more decisive in the challenges faced by beginning teachers. Based on the results of this study, the following suggestions are presented:

- $\quad$ Elective courses can be added to pre-service teacher education curricula to increase the cultural awareness of prospective teachers and to facilitate their adaptation to physical, social and cultural differences and conditions.

- $\quad$ Pre-service teacher education should be able to prepare prospective teachers for outof-school (relations with colleagues, administrators, parents, society) situations so that they can adapt effectively to their colleagues, school administrators, school climate and conditions in their professional lives.

- $\quad$ Beginning teachers were found to have the most difficulties due to the inadequate physical infrastructure and facilities of the school. In this case, the deficiencies caused by the physical infrastructure and facilities of the schools should be eliminated.

- $\quad$ The classroom size should be kept at a reasonable number (maximum 20-25 students) in schools.

- In-service seminars and teacher induction programs should be organized taking into account the challenges that beginning teachers face most in the first year of the profession.

- In order to determine different aspects of the challenges faced by beginning teachers, more studies can be done by taking the opinions of teachers, school administrators, and inspectors apart from the beginning teachers.

\section{References}

Abosede, S. C. (2018). School location, class size and teaching experience as determinants of academic achievement of students' in Lagos State. KIU Journal of Humanities, 2(2), 243252.

Akdag, Z. (2014). Beginning early childhood education teachers' struggles in remote areas. International Journal of Educational Researchers, 5(3), 1-13.

Ballantyne, J. (2005). Effectiveness of pre-service music teacher education programs: Perceptions of early-career music teachers (Unpublished doctoral thesis). Centre for Innovation in Education. 
Barbara, B. L., \& Grady, M. L . (2007). From first-year to first-rate: Principals guiding beginner teachers. USA: Corwin Press.

Barkauskaite, M., \& Meskauskiene, A. (2017). Problems and support needs of beginning teachers during the first years in the profession. European Journal of Social Science Education and Research, 4(3), 89-95.

Bashir, L. (2017). Job satisfaction of teachers in relation to professional commitment. The International Journal of Indian Psychology, 4(4), 1-8.

Blatchford, P., Bassett, P., \& Brown, P. (2011). Examining the effect of class size on classroom engagement and teacher-pupil interaction: Differences in relation to pupil prior attainment and primary vs. secondary schools. Learning and Instruction, 21(6), 715-730.

Bostock, J. (2019). Exploring in-service trainee teacher expertise and practice: Developing pedagogical content knowledge.Innovations in Education and Teaching International, 56(5), 605-616.

Bressman, S., Winter, J. S., \&Efron, S. E. (2018). Next generation mentoring: Supporting teachers beyond induction. Teaching and Teacher Education, 73, 162-170.

Darling Hammond, L. (2000). How teacher education matters. Journal of Teacher Education, 51(3), 166-73.

DePaul, A. (2000). Survival guide for new teachers: How new teachers can work effectively with veteran teachers,parents, principals, and teacher educators.U.S. Department of Education: Office of Educational Research and Improvement.

Duran, E., Sezgin, F., \& Coban, O. (2011). Examining candidate classroom teachers' compliance and socialization process. Dumlupinar University Journal of Social Sciences, 31, 465-478.

Ergunay, O., \& Adiguzel, O. C. (2019). The challenges of beginning teachers in their first year of teaching career and their sources.Journal of Qualitative Research in Education, 7(3), 1080-1099.

Erturk, S. (2013). Egitimde "program" gelistirme[Curriculum development in education]. Ankara: Edge Academy Publications.

Farrell, T. S. (2012). Novice-service language teacher development: Bridging the gap between preservice and in-service education and development. TESOL Quarterly, 46(3), 435-449.

Farrell, T. S. (2016). Surviving the transition shock in the first year of teaching through reflective practice. System, 61, 12-19.

Fraenkel, J. R., Wallen, N. E., \& Hyun, H. H. (2012). How to design and evaluate research in education. USA: The McGraw-Hill Companies, Inc.

Gaikhorst, L., Beishuizen, J., Roosenboom, B., \& Volman, M. (2017). The challenges of beginning teachers in urban primary schools. European Journal of Teacher Education, 40(1), 46-61.

Goodwin, B. (2012). Research says/new teachers face three common challenges. Supporting Beginning Teachers, 69(8), 84-85.

Hennissen, P., Beckers, H., \&Moerkerke, G. (2017). Linking practice to theory in teacher education: A growth in cognitive structures. Teaching and Teacher Education, 63, 314325.

Jensen, B., et al (2012). The experience of new teachers: Results from TALIS 2008. OECD Publishing.

Keengwe, J., \& Adjei-Boateng, E. (2012). Induction and mentoring of beginning secondary school teachers: A case study. International Journal of Education, 4(2), 250-260.

Kumi-Yeboah, A., \& James, W. (2012). Transformational teaching experience of a novice teacher. Adult Learning, 23(4), 170-177. 
Lancaster, J., \& Bain, A. (2019). Designing university courses to improve pre-service teachers' pedagogical content knowledge of evidence-based inclusive practice. Australian Journal of Teacher Education, 44(2), 51-65.

Lim, C. P., Cock, K., Lock, G., \& Brock, G. (2009). Innovative practices in pre-service teacher education: An Asia-pacific perspective. The Netherlands: Sense Publishers.

Michel, H. A. (2013). The first five years: Novice teacher beliefs, experiences, and commitment to the profession (Unpublished doctoral thesis). San Diego: University of California.

Ministry of Development. (2013). Socio-economic development ranking research of provinces and regions [SEGE-2011]. General Directorate of Regional Development and Structural Adjustment.

Monica, S., \& Kuswandono, P. (2019). Benefits and challenges of teacher professional development program implementation: English teachers' perspectives. International Journal of Indonesian Education and Teaching, 3(2), 253-265.

Mudzingwa, K., \& Magudu, S. (2013). Idealism versus realism: Expectations and challenges of beginning teachers in three districts of Masvingo province, Zimbabwe. Journal of Studies in Social Sciences, 3(1), 33-54.

Ozgan, H. (2013). Trainee teachers' expectations from school administrators during their socialization processes. Education and Science, 38(168), 17-29.

Patton, M. Q. (2002). Qualitative research \& evaluation methods. USA: Sage Publications, Inc.

Roehrig, A. D., Pressley, M., \& Talotta, D. A. (2002). Stories of beginning teachers: First years challenges and beyond. Indiana: University of Notre Dame Press.

Sali, P., \& Kecik, I. (2018). Challenges of first years of teaching in Turkey: Voices of novice EFL teachers. English Language Teaching, 11(4), 117-131.

Sari, M. H., \& Altun, Y. (2015). Problems faced by beginning primary education teachers. Hacettepe University Journal of Education, 30(1), 213-226.

Senemoglu, N. (2007). High status Turkish female administrators in higher education in Turkey. Advancing Women in Leadership Online Journal.

Senemoglu, N. (2011). How effective are initial primary teacher education curricula in Turkey: Student teacher faculty and teachers let us know. International Journal of Curriculum and Instructional Studies, 1(1), 35-47.

Senemoglu, N. (2015). Gelisim, ogrenmeveogretim: Kuramdanuygulamaya [Development, learning and teaching: From theory to practice]. Ankara: Yargi Publications.

Shann, M. H. (2014). Professional commitment and satisfaction among teachers in urban middle schools. The Journal of Educational Research, 92(2), 67-73.

Sharma, D. (2019). Job satisfaction and professional commitment of teacher educators: An empirical study. International Journal of Recent Scientific Research, 10(09), 34651-34657.

Solomon, C. B. (2008). The relationships among middle level leadership, teacher commitment, teacher collective efficacy, and student achievement (Unpublished doctoral thesis). Columbia: Missouri University.

Thompson, S., \& Power, L. (2015). Pre-service teacher training. HEART (Health \& Education Advice \& Resource Team) Helpdesk Report.

TokerGokce, A. (2013). Classroom teachers' professional problems in their induction period. Dicle University Ziya Gokalp Journal of Education, 21, 137-156.

Vikaraman, S. S., Mansor, A. N., \& Hamzah, M. I. M. (2017). Mentoring and coaching practices for beginner teachers-A need for mentor coaching skills training and principal's support. Creative Education, 8(1), 156-169.

Yesilyurt, E., \& Karakus, M. (2011). The problems teachers encountered during the candidacy process. International Online Journal of Educational Sciences, 3(1), 261-293. 


\section{Biographical notes:}

Dr. Ishak Kozikoglu is an Associate Professor in the Department of Educational Sciences, Division of Curriculum and Instruction, at Van Yuzuncu Yil University, Turkey. His current research interests are curriculum studies, instructional issues, teacher education, cultural issues and teacher professional development.

Dr. Nuray Senemoglu is a Professor in the Department of Educational Sciences, Division of Curriculum and Instruction, at Hacettepe University, Turkey. His current research interests are curriculum studies, curriculum development, curriculum evaluation, teacher education and instructional issues. 